\title{
PANDEMIC LEARNING ONTOLOGY: METHODOLOGICAL ASPECTS TO ASSESS SKILLS IN A PUBLIC HEALTH EMERGENCY
}

\author{
Marcos Lévano ${ }^{1}$, Billy Peralta ${ }^{2}$ and Gabriel Venegas ${ }^{1}$ \\ ${ }^{1}$ Computer Engineering Department, Catholic University of Temuco, Ave. Manuel Montt 56, Mailbox 15-D, \\ Tетисо, Chile \\ ${ }^{2}$ Departamento de Ciencias de la Ingeniería, Universidad Andres Bello, Antonio Varas 880, piso 6, Providencia, \\ Región Metropolitana, Chile
}

\begin{abstract}
The purpose of this work is to show the experience of methodological aspects which were used to assess competencies with regard to conceiving, designing, implementing and operating (CDIO), in a curriculum for competencies in the face of state of emergency in public health due to coronavirus. The situation and advances are displayed as a case study, in training civil engineering professionals in computer science at the Catholic University of Temuco (CUT) in Chile.

The questions intented to be resolved are: Is it possible to improve the capacities of students from the Araucanía region (Chile) in a social-economic-cultural system, through teaching and learning based on education which allows them to discover, expand and exploit the improvement of the training of professional human capital with competencies in an emergency situation in public health due to coronavirus?. The process of validation of competencies responds to conceive, design, implement and operate (CDIO) being adapted. The way in which the transition in the levels of competencies that the progressing student advances occurs is achieved in different teaching and learning activities through online training. The implementation of competency validation is produced in different contexts in the phases: conceive, design, implement and operate, which have had to be faced by teachers, instructors, assistants for the achievement of students.
\end{abstract}

\section{KEYWORDS}

Coronavirus, Pandemic, Educational Evaluation, Competency Training, CDIO, Ontology

\section{INTRODUCTION}

On March 18, 2020, a state of constitutional catastrophe exception was decreed in Chile, due to public calamity in the territory of Chile.

Due to the COVID-19 coronavirus pandemic, a virus which has produced a global alarm (Chen et al., 2020; Geldsetzer, 2020). Educational institutions throughout the country were closed and all: boys, girls and young students, as well as the general population (except those who performed essential services), were ordered to remain confined to their homes, until the end of the state of alarm, given this seems to be the most effective non-clinical measure to stop the advance of the pandemic (Choe, \& Choi, 2020; Kim et al., 2020; Prem et al., 2020).

Teachers had to innovate in the short term with the means at their disposal, a structure which has allowed a good part of the students of all educational stages to continue learning. Since the beginning of the pandemic, 1,200 university students have already dropped out in the case of the Catholic University of Temuco, of which $85 \%$ suspended their studies.

Several trends have boost changes in teaching ways around the world. Some of these trends are globalization, advancements in technology and the new organizational structures of companies and job organization (Lévano \& Herrera, 2012). A variety of international initiatives have ended up becoming models, methodologies, and educational practices that have been incorporated to higher education. A common denominator in many of these educational proposals is the orientation towards education based on 
competences or skills. Competences are those behaviors, abilities, and visible aptitudes that people contribute in a specific field of activities to function effectively and successfully.

The alumni from computer engineering of our university poses a good background in basic sciences, engineering sciences, management of specific contents (Lévano \& Herrera, 2012). The new setting (Lévano, 2017) of the program was developed by making questions to employers, ex-students, other universities, international organizations specialized in the area of computer engineering science (mainly from the Association for Computing Machinery), consultations on studies about teaching engineering (CDIO model) (Crawley et al., 2007), and studies about higher education in Chile and some future changes (OCDE -Organization for Economic Co-operation and Development, and World Bank) (OCDE, 2009), (CNIC, 2010).

This study addresses the process in which how to evidence cognitive and metacognitive processes is demonstrated (Lévano \& Fernández, 2015) in order to achieve the competences. The process of evidencing competences meets with the model CDIO being adapted to the program. The progression of it in the validation of competences is reached through a number of activities of teaching, and learning and the implementation of this process is achieved in several moments during the program in the four stages of CDIO (Crawley et al., 2007).

The present work introduces, firstly, the educational model of Catholic University of Temuco by competencies, then an ontology of validation of competences in times of pandemic for the adapted CDIO, afterwards the progress of results, then the conclusions and future work. Finally, the references.

\section{UCT EDUCATIONAL MODEL}

In our university, we define competence as: "to know how to behave, using our own means and outside resources in order to solve real problems in an effectively and ethically responsible manner" (Lévano \& Herrera, 2012). We also distinguish two kinds of competences or skills, generic competences, which are shared among all the programs and the specific competences which are directly related to the areas of study of each program.

The educational model in our university is based on five axes. Therefore, the Engineering Computer program is set in the same way (Lévano \& Herrera, 2012; Lévano \& Fernández, 2015).

1) Model of education based on competences: we are committed to managing the quality of learning, so we have implemented four specific competences that are vital for the education and development of the students and ten generic competences stipulated by the university.

2) Significant learning focused on students.

3) Ongoing education: we hope that our students keep studding after they graduate, in post graduate levels that develop and increase the complexity of the development of the human resources among the students.

4) Information technologies in the process of learning and teaching: based on what is stipulated in the curriculum, we have intensively incorporated ICT as an important part of the evaluation and teaching processes in all the subjects of the program.

5) Humanistic and Christian education: our globalized society demands ethical professionals with robust knowledge about their specific area of study, ability to face problems from different perspectives, and a high capacity for handle a variety of competences or skills.

These abilities are developed throughout the five years of study by the validation of the generic competences.

\subsection{Engineering Computer Science Program}

The curriculum program operates based on four specific competences according to the stipulations of the university (Lévano, 2017; Herrera et al., 2018).

Software development: The students are able to give solutions by the development of software for specific problems, by using a software engineering approach integrating technical, ethical, social, legal and economic aspects. 
ICT management: The students are able to manage hardware and software technology systems in an organized way, in order to automate management systems and production processes.

Modeling and application of computer science procedures: The students create and apply solutions related to informatics to solve real problems, applying computer science methods, taking care of abstract, logical, and scientific aspects of science. To do so, they use algorithmic methods in the automation process of engineering information.

Application of engineering science: The students implement mathematical and engineering models, as well as models from basic sciences by using logical and reasoning skills, in order to engage themselves in problems of analysis and design of technological systems based on software, linked to engineering special areas.

\section{ONTOLOGY FOR VALIDATION OF COMPETENCIES}

The competences validation process was developed based on the following strategies and developed by the work methodology which consists of 5 situations: Situation 1: Online classes; Situation 2: Forums; Situation 3: Follow-up controls; Situation 4: Group tasks; Situation 5: Group project.

\section{Strategies}

Work meetings: these meetings are performed by an executive board of teachers in the area of computing and other disciplines. The function of these meetings is to evaluate and discuss some situations like: how to distinguish learning difficulties among students, how to generate communication between teachers, choosing advanced students to assist partners having difficulties, developing projects to support the student community, discussing about mechanisms to validate skills and competences and to develop evaluation guidelines.

The topics can be gathered as followed: Problems of specific students (check behavior in each group); Methods to validate generic competences; Performance of each group; Discussion of topics in a vertical way.

There is a coordinator who keeps records of these issues and who moderates and prioritizes topics addressed and the actions to be derived from these meetings. The development strategy was adapted in meetings via Google meet / Zoom / Collaborate.

Integration of competences workshops: Evaluation processes have been carried out every year to evaluate the integration of the development of competences in a horizontal way. They are practical workshops to generate challenges, creativity, and innovation among students in several ways, for example, on a personal or attitudinal level, and how to use their knowledge. The development strategy was Google Meet for presentations and GIT and GITKRAKEN for version control of software product design processes.

Feedback: feedback is done at every moment, in all the subjects. It is accomplished through a learning resource center and also, it is done by all teachers. Feedback takes place in mixed hours, in which the teachers work individually or in groups with the students, as stipulated by the educational model. The objective is to solve analytic, application, or knowledge problems. The development strategy was carried out via webinars and Telegram/WhatsApp.

Peer tutoring: it is developed in each subject that allows intervention of other students. The objective is that older or advanced students help their partners. To do so, focused peer tutorials and tasks with the learning resource center are promoted. The development strategy was carried out via webinars.

Advisory services for teachers: every year, this strategy allows teachers to improve their pedagogical practices. They participate in workshops, training and guided classes. They are supported by the teaching innovation center of the university. The development strategy was carried out via webinars, and academic council meetings of professors via Google Meet. Messaging via LMS Blackboard. 
Record book: we keep track of all the generated and validated knowledge that students achieve in the different topics of the educational process. It allows validating competences, making self-assessments and making interventions in weak areas in medium term. The development strategy was carried out using Google DRIVE, Dropbox as digital repositories.

Control and tracking of professional training: in this stage of the educational process, we check, orient, guide and evaluate the validation of the competences in the work place. The evaluations are made taking into account our own formative discipline and the rules of each place of work in which the professional training is done. The strategy, in situations according to the type of practice, has been to establish work in online mode.

Learning guidelines: it is based on the triple instrument according to the methodology, the assessment and learning outcomes or objectives of the subjects. To develop the guidelines, we worked on activities based on the development of the knowledge of knowing, being, and making. The strategy aims to generate and design e-learning material and VLO (virtual learning objects).

\subsection{Alignment of CDIO with the Curriculum}

The alignment of the process of CDIO (Crawley et al., 2007; Lévano, 2020) with the curriculum has been implemented based on the development of the graduated profile. A Computer Engineer graduated from UCT has a set of competences and a robust basis in engineering sciences that allows him to work in the areas related to software development and ICT. To enhance characteristics that are highly demanded by the working market, and to promote the identity seal of the university, we have boosted the competences of team work, creativity, and innovation.

\subsubsection{Scheme of Competences Development}

The process of developing competences in environments occurs in the classrooms, laboratories, visits, professional job practice, workshops, seminars, and final papers, all as described in the educational model proposed by the university. The process of experiencing the developing of competences goes along with the contexts of active, reflexive, conceptual and application experimentation, see figure 1.

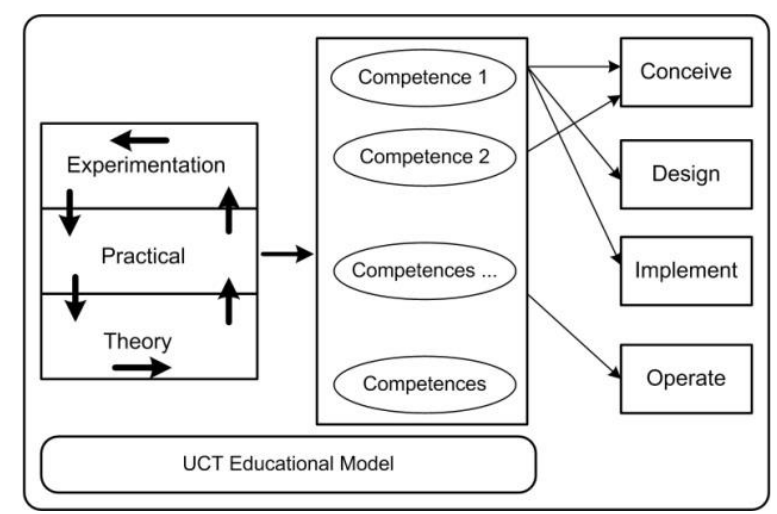

Figure 1. Scheme of competences development in the educational guideline

In table 1, the relationship between specific competences and CDIO model is shown. Generic and specific competences go along together during the process of validation, and each subject can incorporate two or more generic or specific competences. 
Table 1. CDIO Model and Specific Competences

\begin{tabular}{|c|c|c|c|c|c|c|c|c|}
\hline $\begin{array}{c}\text { Specific } \\
\text { Competences }\end{array}$ & Conceive & Design & Implement & Operate & $\begin{array}{c}\text { Generic competences in } \\
\text { the curriculum }\end{array}$ & & evel & \\
\hline $\begin{array}{l}\text { ICT } \\
\text { management }\end{array}$ & $X$ & $X$ & $X$ & $\mathrm{X}$ & \multirow{4}{*}{$\begin{array}{l}\text { Ethical Action; Respect } \\
\text { and appreciation of } \\
\text { diversity; Collaborative } \\
\text { work; Creativity and } \\
\text { innovation; Autonomous } \\
\text { Learning. }\end{array}$} & 1 & 2 & 3 \\
\hline $\begin{array}{l}\text { Modeling and } \\
\text { application of } \\
\text { computer } \\
\text { science }\end{array}$ & & $\mathrm{X}$ & $X$ & & & 1 & 2 & 3 \\
\hline $\begin{array}{l}\text { Software } \\
\text { development }\end{array}$ & $X$ & $X$ & $X$ & $X$ & & 1 & 2 & 3 \\
\hline $\begin{array}{l}\text { Application of } \\
\text { engineering } \\
\text { science }\end{array}$ & & $\mathrm{X}$ & $\mathrm{X}$ & $\mathrm{X}$ & & 1 & 2 & 3 \\
\hline
\end{tabular}

\subsubsection{CDIO in the Development of Specific and Generic Competences}

During the first year "to operate" is worked, while "to implement and to operate" are worked during the second and third year. During the fourth year "to design, to implement and to operate" are worked. Finally, during the fifth year "to conceive, to design, to implement and to operate" are worked altogether. During first year we begin with the vertical implementation and during second year we implement the horizontal integration of competences. This process is sequential and it is also combined along the subjects and the years. For example in figure 2, basic science knowledge is developed in activities inside the subject, because that course is focused on fundamental knowledge. That knowledge is manifested in a horizontal way of competences. In the figures 3 and 4 below we can observe what happens during the rest of the years.

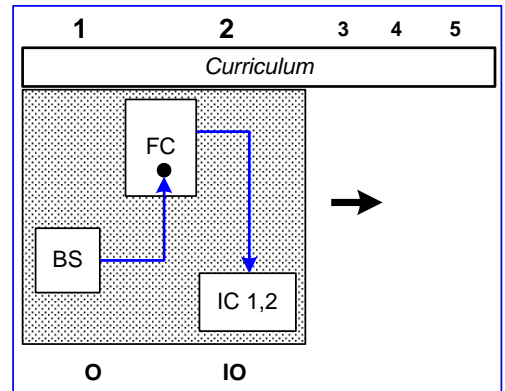

Figure 2. To operate (O); to implement and to operate (IO)

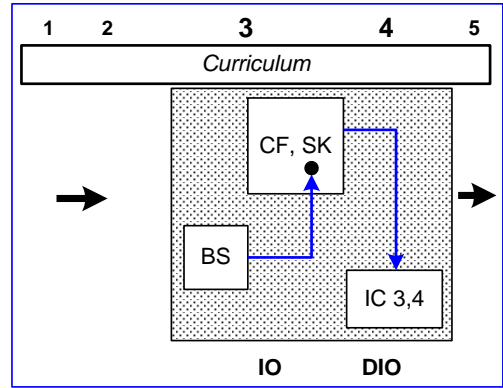

Figure 3. To implement and to operate (IO); Design, Implement and Operate (DIO)

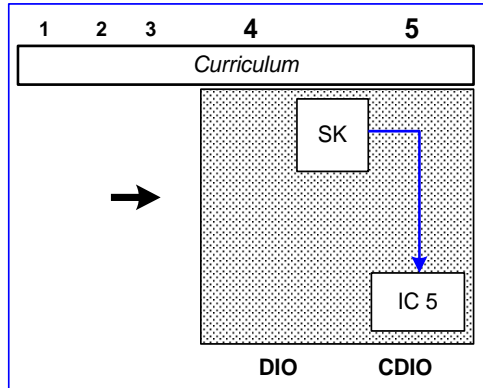

Figure 4. Design, Implement and Operate (DIO); Conceive, Design, Implement and Operate (CDIO)

Notes: (FC) fundamental knowledge; (BS) basic sciences; (IC) integration competences; (SK) specialty knowledge.

\section{RESULTS AND DISCUSSIONS}

The progress of the results achieved were implemented in the semester II-2020 in the Civil Engineering in Computer Science degree at Catholic University of Temuco (CUT). To show the progress made, it was applied in four subjects.

Data Description, 
Table 2. Description of the data under study

\begin{tabular}{lclcc}
\hline \multicolumn{1}{c}{ Subject } & $\begin{array}{c}\text { Total } \\
\text { Students }\end{array}$ & \multicolumn{1}{c}{ General competencies } & $\begin{array}{c}\text { Level of } \\
\text { competence }\end{array}$ & $\begin{array}{c}\text { Year on the } \\
\text { curriculum }\end{array}$ \\
\hline Introduction to databases & 10 & Autonomous Learning & 1 & 1 \\
\hline Integration Workshop II & 34 & $\begin{array}{l}\text { Creativity and innovation } \\
\text { Collaborative work } \\
\text { Oral and written communication }\end{array}$ & 2 & 2 \\
\hline Computer Theory & 32 & $\begin{array}{l}\text { Appreciation and respect for } \\
\text { diversity }\end{array}$ & 1 & 4 \\
\hline Business Intelligence & 24 & Ethical Performance & 2 & 4 \\
\hline Total & 100 & \multicolumn{1}{c}{ 6 competencies } & & 4 \\
\hline
\end{tabular}

Incidence of causal variables, which worried the students. In the figure 6, we can see that contagion and uncertainty are over $60 \%$ of concern in the face of the pandemic, (see figure 5).

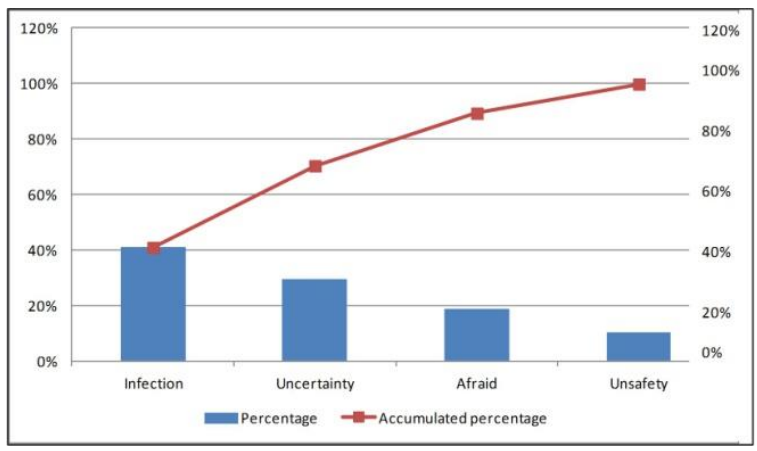

Figure 5. Pareto diagram regarding causal variables

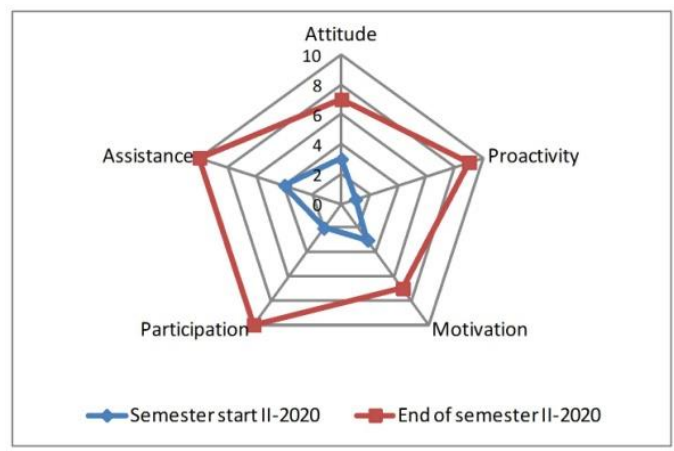

Figure 6. Radial diagram of teacher perception belief

In figure 6, we can observe the perception of professors regarding the teaching and learning process of students, referring to achievement learning (see figures 7, 7(a), 7(b), 7(c) y 7(d)). See also focus groups in the table 3.

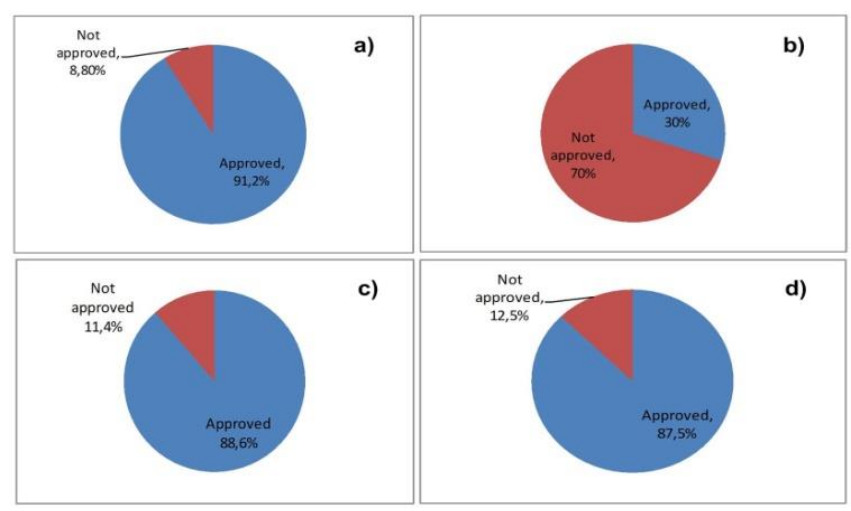

Figure 7. a) Approval in progress of Integration Workshop II, $\mu=5.6, \sigma=1.8$; b) Approval in progress of Introduction to

Databases, $\mu=2.7, \sigma=4.7$; c) Approval in progress Computer Theory, $\mu=5.1, \sigma=1.6$; d) Approval in progress Business Intelligence, $\mu=5.6, \sigma=3.4$ 
Table 3. Focused discussion

\begin{tabular}{|c|c|c|c|}
\hline $\begin{array}{l}\text { Focus } \\
\text { group }\end{array}$ & Design & Questions & Analysis \\
\hline \multirow[t]{4}{*}{1} & \multirow{4}{*}{$\begin{array}{l}10 \text { students; } \\
\text { Age } 18 \text { to } 20 ; \\
\text { Duration } 15 \\
\text { minutes; } \\
\text { Number of } \\
\text { courses: } 2 \\
\text { Courses: } \\
\text { Introduction to } \\
\text { Database Systems } \\
\text { and Integration } \\
\text { Workshop II. }\end{array}$} & $\begin{array}{l}\text { How did you perform during the } \\
\text { Pandemic learning process? }\end{array}$ & $\begin{array}{l}\text { In this sample, deficiency is reported due to a } \\
\text { large number of people who failed. } \\
\text { Implication due to motivation and attendance. }\end{array}$ \\
\hline & & Whose pressure do you feel to study? & $\begin{array}{l}\text { It is observed that from their parents and / or } \\
\text { guardians they feel pressure due to the cost of } \\
\text { the degree. }\end{array}$ \\
\hline & & $\begin{array}{l}\text { Have you felt assisted by the professor } \\
\text { in the learning and teaching processes? }\end{array}$ & $\begin{array}{l}\text { They are aware they had the necessary and } \\
\text { frequent support from their professors. } \\
\text { Implication of affect due to attitude and } \\
\text { participation. }\end{array}$ \\
\hline & & $\begin{array}{l}\text { Were the remote support hours } \\
\text { sufficient? }\end{array}$ & $\begin{array}{l}\text { They assume the channels existed, but they } \\
\text { still feel a difference because of the digital } \\
\text { divide. }\end{array}$ \\
\hline \multirow[t]{5}{*}{2} & \multirow{5}{*}{$\begin{array}{l}20 \text { students; } \\
\text { Age } 2 \text { to } 25 ; \\
\text { Duration } 20 \\
\text { minutes; } \\
\text { Number of } \\
\text { courses: } 2 \\
\text { Courses: Business } \\
\text { Intelligence and } \\
\text { Computer Theory. }\end{array}$} & $\begin{array}{l}\text { Was the methodology applied adequate } \\
\text { to develop your skills? }\end{array}$ & $\begin{array}{l}\text { It is believed the instances of: online classes; } \\
\text { forums; follow-up controls; group tasks; and } \\
\text { group project, give a balance and adequate } \\
\text { aspects for their learning experience. }\end{array}$ \\
\hline & & $\begin{array}{l}\text { Was the academic demand from } \\
\text { professors excessive or low? }\end{array}$ & $\begin{array}{l}\text { They complain saying some professors } \\
\text { exceeded the product and the estimated } \\
\text { timing. }\end{array}$ \\
\hline & & $\begin{array}{l}\text { Do you think you have acquired } \\
\text { knowledge in "knowing" and "doing"? }\end{array}$ & $\begin{array}{l}\text { They are aware they reached their goal. In } \\
\text { some cases, they still feel they need the } \\
\text { physical classroom, since they think they } \\
\text { missed completing some tasks in situ and } \\
\text { having their professors physically present for } \\
\text { support. }\end{array}$ \\
\hline & & $\begin{array}{l}\text { Have the technological platforms used } \\
\text { been consistent with the teaching and } \\
\text { learning process? }\end{array}$ & $\begin{array}{l}\text { They are aware the study media and artifacts, } \\
\text { through the LMS Moodle platform and } \\
\text { Blackboard, allowed a substantial and } \\
\text { situational support instance. }\end{array}$ \\
\hline & & $\begin{array}{l}\text { Was the leadership style they } \\
\text { performed more transactional, } \\
\text { transformational, or liberal? }\end{array}$ & $\begin{array}{l}\text { They believe in group work; they have grown } \\
\text { in the way they face situations. Other students } \\
\text { still require record of attendance. }\end{array}$ \\
\hline
\end{tabular}

\section{CONCLUSIONS}

It is interesting to note the students adapted to the situations of the evaluation methodology and styles. They mention the resources provided by professors should be of support to their PLE and PLN (Castañeda et al., 2016; Dabbagh, Fake, \& Zhang, 2019). They suggest short video files of 10-15 minutes. So they also consume more files with content. On the other hand, they themselves map out a constructivist vision which feeds their PLE and then this is shared in their PLN.

Professors and instructors have had to move from a belief and habit in the traditional way to build their materials for teaching and learning. This has led them to develop divergent creativity, to exploit the use and application of ICT tools. Given that currently formators face pressure and adaptation in a VICA world (Bauman, 2007).

The social action theory of E. Goffman (Goffman, 2010) indicates human behavior depends on its settings and on personal relationships. This has helped the apprentice to strengthen ties of ties between people and their acquaintances, since the subject does not exist in isolation. 
Through this work ontology, a mechanism is intended to validate general competencies in the curriculum for a major in computer engineering in times of emergency due to coronavirus, where the CDIO process is performed. This does not limit the trainer to innovate new strategies which help in the teaching and learning process of students.

\section{REFERENCES}

Bauman, Zygmunt, Miedo líquido. La sociedad contemporánea y sus temores, Paidos, Barcelona, 2007.

Castañeda, L., Cosgrave, M., Marín, V., \& Cronin, C. (2016). Personal Learning Environments: PLE Conference 2015 Special Issue Guest Editorial. Digital Education Review, 29. Retrieved from http://greav.ub.edu/der

Chen, Y., Jin, Y. L., Zhu, L. J., Fang, Z. M., Wu, N., Du, M. X., ... \& Yao, Y. S. (2020). The network investigation on knowledge, attitude and practice about COVID-19 of the residents in Anhui Province. Zhonghua yu Fang yi xue za zhi Chinese Journal of Preventive Medicine, 54(4), 367-373. http://doi.org/dtqg

Choe, Y. J., \& Choi, E. H. (2020). Are We Ready for Coronavirus Disease 2019 Arriving at Schools? Journal of Korean Medical Science, 35(11). http://doi.org/ggq848

Crawley, E., Malmqvist, J., Östlund, S., Brodeur, D. (2007). Rethinking engineering education: The CDIO approach. Vol. 14, 286 p.

CNIC. (2010). Agenda de Innovación y Competitividad 2010-2020. CNIC: Consejo Nacional de Innovación para la Competitividad, 2010, Chile.

Dabbagh, N., Fake, H., \& Zhang, Z. (2019). Student Perspectives of Technology Use for Learning in Higher Education. RIED. Revista Iberoamericana de Educación a Distancia, 22(1), pp. 127-152. doi: http://dx.doi.org/10.5944/ried.22.1.22102

Geldsetzer, P. (2020). Use of Rapid Online Surveys to Assess People's Perceptions During Infectious Disease Outbreaks: A Cross-sectional Survey on COVID-19. Journal of medical Internet research, 22(4), e18790. http://doi.org/ggq7t8

Goffman, E. (2010). Comportamento em lugares públicos: notas sobre a organização social dos ajuntamentos. Vozes.

Jieming Ma, Chili Li, Hai-Ning Liang, "Enhancing Students' Blended Learning Experience through Embedding Metaliteracy", Education Research International, vol. 2019, Article ID 6791058, 8 pages, 2019. https://doi.org/10.1155/2019/6791058

Kim, S., Kim, Y. J., Peck, K. R., \& Jung, E. (2020). School Opening Delay Effect on Transmission Dynamics of Coronavirus Disease 2019 in Korea: Based on Mathematical Modeling and Simulation Study. Journal of Korean medical science, 35(13). http://doi.org/dtqx

Kristina Edström (2020) The role of CDIO in engineering education research: Combining usefulness and scholarliness, European Journal of Engineering Education, 45:1, 113-127, DOI:10.1080/03043797.2017.1401596

Levano, M. (2017). Methodology for Knowledge Management and Self-Directed, Science Program Engineering Computing. In Issa, T., Kommers, P., Issa, T., Isaías, P., \& Issa, T. B. (Eds.), Smart Technology Applications in Business Environments (pp. 63-81). IGI Global. http://doi:10.4018/978-1-5225-2492-2.ch004

Levano M., Fernández C. (2015) A Model for a Physical and Virtual Environment for Extreme Feedback in the Development of the Metacognition Supported by TICS: The Computer Engineer Career as Case of Study. In: Park J., Stojmenovic I., Jeong H., Yi G. (eds) Computer Science and its Applications. Lecture Notes in Electrical Engineering, vol 330. Springer, Berlin, Heidelberg. https://doi.org/10.1007/978-3-662-45402-2_187

M. A. Lévano, "Effects of Cycle Evaluation on Peer Learning: Competency Assessment, Case Study, Catholic University of Temuco, Chile," 2020 11th International Conference on Information, Intelligence, Systems and Applications (IISA, Piraeus, 2020, pp. 1-6, doi: 10.1109/IISA50023.2020.9284369.

M. A. Lévano and O. A. Herrera, "Validation Strategies of Competences in a Computer Science Curriculum," 201231 st International Conference of the Chilean Computer Science Society, Valparaiso, 2012, pp. 9-11, doi: 10.1109/SCCC.2012.8.

O. A. Herrera, M. Lévano and J. Rojas-Mora, "Evaluating achievement of competences through integration workshops: an approach with strategies supported by ICT," 2018 37th International Conference of the Chilean Computer Science Society (SCCC), Santiago, Chile, 2018, pp. 1-7, doi: 10.1109/SCCC.2018.8705267.

OECD/The World Bank (2009), La Educación Superior en Chile, Revisión de Políticas Nacionales de Educación, Ministry of Education, Chile, Santiago de Chile, https://doi.org/10.1787/9789264054189-es.

Prem, K., Liu, Y., Russell, T. W., Kucharski, A. J., Eggo, R. M., Davies, N., ... \& Abbott, S. (2020). The effect of control strategies to reduce social mixing on outcomes of the COVID-19 epidemic in Wuhan, China: a modelling study. The Lancet Public Health. https://www.thelancet.com/action/showPdf?pii=S2468-2667\%2820\%2930073-6 